\title{
The status of Asthenopus curtus (Hagen) (Ephemeroptera: Polymitarcyidae) (1)
}

\author{
Lewis Berner $\left({ }^{2}\right)$
}

\begin{abstract}
Study of a series of reared adult male and female mayflies in the genus Asthenopus from the Amazon demonstrated that males had been described by Hagen as A. curtus and females as A. amazonicus. As only a single species is represented by the strongly sexually dimorphic males and females, all should be designated as A. curtus (Hagen) and A, amazonicus (Hagen) is, therefore, a synonym.
\end{abstract}

In the summer of 1976, Dr. Ernest S. Del Fosse $^{3}$ brought me a mayfly nymph which, reportedly, had been found tunneling in tissues of the water hyacinth, Eichhornia crassipes, in the Amazon River at Manaus, Brazil. As Dr. Del Fosse is investigating possible biological control agents for this pest species of floating plant in the United States, he was interested in the nymph and its potential in this regard. Someone had correctly identified the specimen as belonging to the genus Asthenopus.

Early in 1977, I learned of Dr. Ulrich Irmler's studies on the Amazon River in the region of Manaus and I wrote to him for his assistance in obtaining information about Asthenopus. He informed me of the studies of Mr. Ricardo Braga, who is working in Brazil on the life history of Asthenopus and its effects in causing deterioration of wood.

$\mathrm{Mr}$. Braga had sent specimens of adults and nymphal exuviae to Dr. Irmler in Germany for identification and $\mathrm{Dr}$. Irmler forwarded them to me. Since I felt that it would be desirable to see additional reared and associated nymphs and adults, I requested such specimens from Mr. Braga, which he provided for me.
As the Braga specimens did not appear to be a new species, it was obvious that they were either Asthenopus curtus (Hagen) or A. amazonicus (Hagen), both species having been reported from Brazil. In atempting to resolve the problem of identification, I obtained a copy, through the courtesy of Dr. Joachim Illies, of the excellent review of the biology and systematics of Asthenopus published by the late $\mathrm{Dr}$ Werner Sattler in 1967. He was puzzled by the discrepancies in the characteristics used to differentiate the species and he reviewed the doubts as to their validity expressed both by Traver (1950) and Demoulin (1955).

According to Ulmer (Traver, 1950), A. curtus can be most easily separated from $A$. amazonicus by the presence in the fore wing of two intercalary veins of about equal length lying between $R_{2}$ and the bisector of the fork in A. curtus. A. amazonicus has three or four such intercalaries in its fore wing. Other characteristics given by Ulmer (1942) are qualitative. For $A$. curtus, he described the hind wing as having a median bisector and vein $M_{2}$ which are relatively short, while in A. amazonicus the bisector and $\mathrm{M}_{2}$ are longer; the network of crossveins of both wings is not conspicuously dense in $A$. curtus but is very dense in $A$. amazonicus, especially along the outer margin. That Ulmer also had doubts of the distinctiveness of the two species is clear from a reading of his footnote 3 (I.c., p. 105) in which he stated that it was not clear that the differences he observed were sufficient for separation.

As a result of my examination of $\mathrm{Mr}$. Braga's specimens, I am now convinced that

(1) - Contribution No 404, Bureau of Entomology, Division of Plant Industry, Florida Department of Agriculture and Consumer Services, Gainesville, Florida, 32602.

(2) - Research Associate, Florida State Collection of Arthropods, Florida Department of Agriculture and Consumer Services, Gainesville.

(3) - Research Entomologist, Lee County Hyacinth Control District, P. O. Box 2239, Fort Myers, Florida 33902. 
the doubts expressed by Dr. Sattler, Dr. Traver, $\mathrm{Dr}$. Demoulin, and Dr. Ulmer as to the validity of $A$. amazonicus were entirely justified. Among the specimens sent to me was a series of ten reared females and ten reared males. The nymphs were collected by Mr. Braga at Lago do Castanho, Municipality of Careiro, near Manaus, Amazonas, Brazil, on November 27, 1976. Using the characteristics given by Ulmer for differentiating the species, I easily identified the females as being $A$. amazonicus. All the males were $A$. curtus.

It became obvious to me that because of sexual dimorphism in this genus Hagen had mistakenly named the females $A$. amazonicus and the males $A$. curtus. There is a striking difference in the size of the two sexes available to me for study with the wing length of the females ranging from 18 to $19.6 \mathrm{~mm}$-all have four intercalary veins between $R_{2}$ and the radial bisector-and the size range for the ten males is from 9.4 to $11.0 \mathrm{~mm}$-all have two intercalaries between $R_{2}$ and the radial bisector. The network of crossveins in the fore wing of the female is much more dense than in that of the male. The drawings of the male and female fore wings (figs. 1 and 2) show these characteristics clearly.

Dr. Sattler (1967), in expressing his doubts as to the validity of $A$. amazonicus, questioned the use of Ulmer's criterion for separating the two species based on the number of intercalary veins. Just as I found in the Braga specimens, Sattler's five males were identified as $A$. curtus, his twelve female subimagoes were A. amazonicus. Obviously, Asthenopus curtus is a pronouncedly sexually dimorphic species, a fact which Hagen did not recognize when he described $A$. amazonicus seventeen years after reporting $A$. curtus from Brazil. When he described $A$. amazonicus, he claimed that Eaton's (1883) illustration of a nameless Brazilian insect (Plate VI, figure 8) was like that of the insect he was describing. Eaton did not give the sex of the mayfly from which his drawing was taken, but I am convinced that it must have been a female. Hagen did not recognize the differences in the venation and these remained unknown until Ulmer noted them in 1942. In view of the above considerations, A. amazonicus must therefore be considered to be a synonym of $A$. curtus.
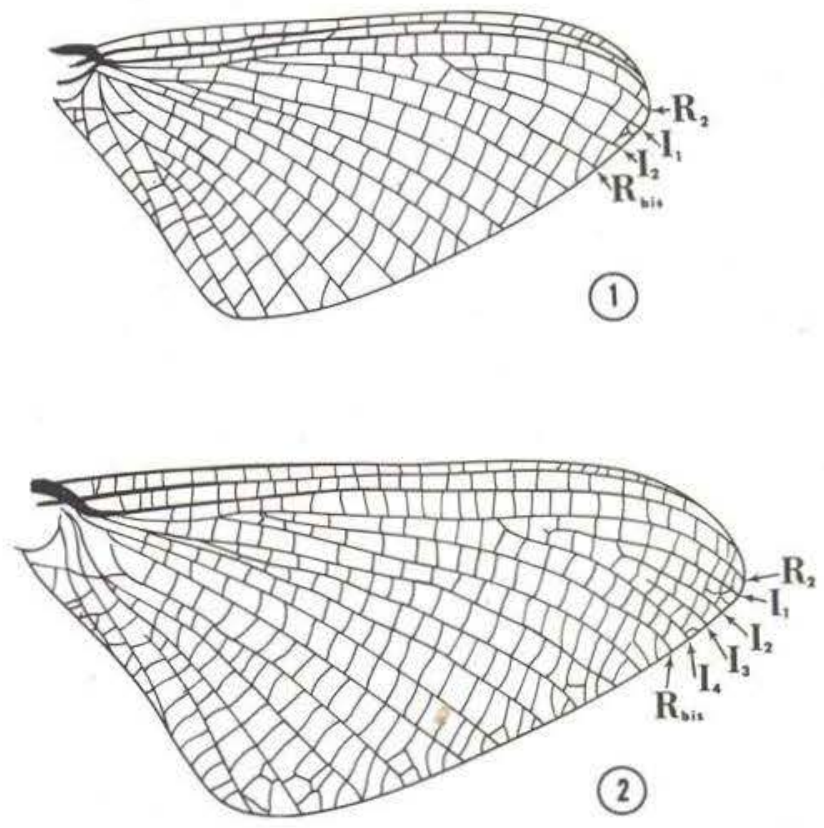

Fore wings of Asthenopus curtus (Hagen). Fig. 1. male; Fig. 2. female. $I_{1}, I_{2}, I_{3}, I_{4}$ radial intercalaries; $R_{b j s}$ radial bisector.

The adaptations of the nymphs of Asthenopus to tunneling and to food gathering have been thoroughly described and illustrated in Sattler's paper. Dr. S. S. Roback (1966) reported collecting a nymph of Asthenopus? sp., which he described and figured. It is likely that this nymph from the headwaters of the Amazon is also $A$. curtus.

\section{RESUMO}

O estudo de uma série de machos e fêmeas de Efemerópteros da Amazônia do gênero Asthenopus criados no laboratório demonstrou que os machos tinham sido descritos por Hagen como A. curtus e as fêmeas como A. amazonicus. Sendo que só uma espécie é representada por estes machos e fêmeas que apresentam dimorfismo sexual bem marcado, todos devem ser designados como A. curtus (Hagen) sendo A. amazonicus um sinônimo. 


\section{LITERATURE CITED}

Demoulin, G

1955 - Une mission biologique Belge au Brésil. Ephéméroptères. Bull. Inst. Toy. des Sci. Natur. de Belg. $31(20): 1-32$.

Eaton, A. E.

1871 - A monograph on the Ephemeridae. Trans. Entomol. Soc. London, $64 \mathrm{p}$.

1883/88 - A revisional monograph of recent Ephemeridae or mayflies. Trans. Linn. Soc. London, 2. Ser. Zool., 3: 1-352.

HAGEN, $\mathrm{H}$.

1888 - Unsere gegenwartige Kenntniss der Epheneren. Stett. Entomol. Zeit., 49(7-9) : 221-232.
ROBACK, S. S.

1966 - The Catherwood Foundation Peruvian-Amazon expedition. VI - Ephereroptera nymphs. Mono. Acad. Natur. Sci. Phila., (14) : 129-199.

SATtLeR, W.

1967 - Uber die Lebensweise, insbesondere das Bauverhalten, neotropischer EintagsfliegenLarv'en (Ephemeroptera, Polymitarcidae). Beit. zur Neotrop. Fauna, 5(2) : 89-110.

Traver, J. R.

1950 - Notes on neotropical mayflies. Part. IV. Family Ephemeridae (continued). Rev. de Entomol., 21(3) : 593-614.

Ulmer, G.

1942 - Alte und neue Eintagsfliegen (Ephemeropteren) aus Sud-und Mittelamerika. Stett. Entomol. Zeit., 103 : 98-128.

(Aceito para publicação em $1 / 2 / 78$ ) 